\title{
WITHIN PLANT DISTRIBUTION OF Anthonomus grandis (COLEOPTERA: CURCULIONIDAE) FEEDING AND OVIPOSITION DAMAGES IN COTTON CULTIVARS
}

\author{
Distribuição vertical de botões florais com danos de alimentação e de oviposição de \\ Anthonomus grandis (Coleoptera: Curculionidae) em cultivares de algodoeiro
}

\author{
José Fernando Jurca Grigolli' ${ }^{1}$, Leandro Aparecido de Souza², \\ Diego Felisbino Fraga ${ }^{2}$, Marina Funichello², Antonio Carlos Busoli ${ }^{2}$
}

\begin{abstract}
The feeding and oviposition behavior of boll weevil in new cotton cultivars is essential for an adequate management. The objective of this study was to evaluate the vertical distribution of squares punctured for feeding and oviposition of the pest in the cultivars NuOPAL, DeltaOPAL, FMT-701, FMX-910 and FMX-993, and record the most and least preferred times of feeding and oviposition. The number of squares used for boll weevil feeding and oviposition were evaluated weekly in three parts of plant canopy. It was observed that, regardless the cultivar, A. grandis preferred to lay eggs in squares located in the upper part and feed on squares in the middle and upper parts. The boll weevil preferred to feed on cultivar FMT-701 in the beginning of the period of cotton flowering and fruiting, and the cultivars NuOPAL, DeltaOPAL, FMX-910 and FMX-993 throughout the whole period of flowering and fruiting. A. grandis preferred to lay eggs on cultivars NuOPAL, FMT-701 and FMX-993 at the beginning and end of flowering and fruiting of plants, while the cultivars DeltaOPAL and FMX-910 are used for oviposition throughout the period of flowering and fruiting.
\end{abstract}

Index terms: Boll weevil, Gossypium hirsutum, feeding preference, oviposition preference, behavior.

\section{RESUMO}

O conhecimento do comportamento de alimentação e de oviposição de Anthonomus grandis em cultivares recentes de algodoeiro é essencial para seu manejo. Neste trabalho, objetivou-se avaliar a distribuição vertical de botões florais com orifícios de alimentação e de oviposição da praga nas cultivares NuOPAL, DeltaOPAL, FMT-701, FMX-910 e FMX-993, bem como registrar as épocas de maior e menor preferência alimentar e de oviposição. O experimento foi conduzido em Jaboticabal, SP, Brasil, safra 2010/2011. Foram realizadas avaliações semanais, baseadas no número de botões florais, utilizados para alimentação e para oviposição pelo bicudo-doalgodoeiro, em três regiões do dossel das plantas. Observou-se que A. grandis preferiu ovipositar em botões florais localizados no terço superior das plantas e se alimentar de botões florais localizados nos terços médio e superior das plantas. A cultivar FMT-701 foi mais utilizada para a alimentação do bicudo, no início do período de florescimento e frutificação, e as cultivares NuOPAL, DeltaOPAL, FMX910 e FMX-993 são utilizadas em todo o período de florescimento e frutificação das plantas. A. grandis preferiu ovipositar nas cultivares NuOPAL, FMT-701 e FMX-993, no início e no final do período de florescimento e frutificação e as cultivares DeltaOPAL e FMX-910 foram mais ovipositadas durante todo o período de florescimento e frutificação das plantas.

Termos para indexação: Bicudo do algodoeiro, Gossypium hirsutum, preferência para alimentação, preferência para oviposição, comportamento.

\section{(Received in may 23, 2012 and approved in november 20, 2012)}

\section{INTRODUCTION}

The cotton boll weevil, Anthonomus grandis Boheman 1843 (Coleoptera: Curculionidae) is one of the major pests of cotton, causing damage to plants in production fields of South America (RIBEIRO et al., 2010).

The damage caused by the pest results from the use of cotton flower and fruit structures for oviposition of adults and feeding of both larvae and adults of $A$. grandis. The boll weevil prefers to feed and lay eggs on developed squares, with a diameter of 5.5 to $8 \mathrm{~mm}$ (SHOWLER, 2005). It was observed that fecundity and oviposition of the weevil females are higher after feeding on these developed buds (SHOWLER, 2004).

The main purpose of studying the vertical distribution of pests in agricultural crops is that this knowledge can accelerate and increase the reliability of insect sampling in a given agricultural area (FERNANDES et al., 2006). The same authors stated that this information

\footnotetext{
¿Universidade Estadual Paulista "Júlio de Mesquita Filho"/UNESP - Departamento de Fitossanidade - Via de Acesso Prof. Paulo Donato Castellane s/n - 14884-900 - Jaboticabal - SP - Brasil - jose_fernando_jg@yahoo.com.br

Universidade Estadual Paulista "Júlio de Mesquita Filho"/UNESP - Departamento de Fitossanidade - Jaboticabal - SP - Brasil
} 
serves for a more precise application of common field practices, e.g., the best place of land or air insecticide application, or to deepen the understanding of the role of natural enemies with a view to maximize the natural biological control. In addition, information on the vertical distribution of insect pests on the host plant is fundamental for the development of sampling strategies (TRICHILO et al., 1993), to decrease time and costs invested in pest monitoring, without reducing the reliability of results (WILSON et al., 1982). Accurate sampling methods are essential to understand the population dynamics of insect pests and effective use of control strategies (NARANJO; FLINT, 1995; ELLSWORTH; MARTÍNEZ-CARRILLO, 2001).

The feeding and oviposition behavior of $A$. grandis in new cultivars is still unknown, which is limiting to the adoption of efficient control strategies. Additionally, the planting system, orchard management, and climate, among other factors, are determinant for the plant-insect interaction. Thus, the purpose of this study was to evaluate the vertical distribution of squares punctured for feeding and oviposition of $A$. grandis at different phenological stages of five cotton cultivars, and to record the periods of major and minor feeding preference and oviposition.

\section{MATERIAL AND METHODS}

The experiment was conducted on an experimental farm of Faculdade de Ciências Agrárias e Veterinárias of the São Paulo State University (FCAV/UNESP), in Jaboticabal, SP, Brazil, in the growing season 2010/2011. The experiment was arranged in a randomized block design in split plots with 15 treatments ( 5 cultivars x 3 parts of plant canopy) and 8 replications. The cotton cultivars DeltaOPAL, NuOPAL (Bollgard I ${ }^{\circledR}$ ), FMT-701, FMX-910 and FMX-993 were assessed, which are the most commonly used cultivars in the major cotton-producing regions of Brazil.

Sowing was done by hand on November 19, 2010, and seven days after emergence (DAE) the seedlings were thinned to an average density of 12 plants per meter. The soil was prepared by plowing once and disking twice and corrected according to the recommendations of Sousa and Lobato (2004). Forty plots were outlined, each of which consisted of six 10-m rows, spaced $0.9 \mathrm{~m}$ apart. The four central plant rows per plot were evaluated, excluding one meter from either end of the rows.

No insecticide and herbicide was applied during the experiment, and weed control was carried out initially with a small tractor-drawn plow and thereafter whenever necessary, by hand. Due to the high rain frequency and high relative humidity from January to March at the experimental site, the benzimidazole and triazole-based fungicide was applied 60, 70 and $80 \mathrm{DAE}\left(0.8 \mathrm{~L} \mathrm{ha}^{-1}\right.$ active ingredient), to all cultivars to prevent the attack of Ramularia leaf spot (Ramularia areola Atk.) and ramulosis (Colletotrichum gossypii var. cephalosporioides Costa). The growth regulator mepiquat chloride $\left(\mathrm{Pix}^{\circledR}\right)$ was applied $45 \mathrm{DAE}$ as recommended for the crop $\left(0.5 \mathrm{~L} \mathrm{ha}^{-1}\right.$ active ingredient), to achieve a plant height between 1.2 and 1.3 $\mathrm{m}$, as recommended for mechanical harvesting (BUSOLI et al., 1994).

Between 52 and 136 DAE, 15 evaluations were performed, covering the period of plant flowering and fruiting of the five cotton cultivars. During the evaluations, five plants per plot were uprooted and analyzed by dividing them into three parts (upper, middle and lower), to record the vertical distribution of squares punctured by the boll weevil for feeding and oviposition in the plant canopy. The number of squares used for feeding and oviposition of the pest was recorded in view of the preference of $A$. grandis for this plant part (SHOWLER, 2005).

Each evaluation was based on careful observation of the number of squares per plant and the number of punctured squares for feeding or oviposition of $A$. grandis in each part of plant canopy. The data were transformed by $(\mathrm{X}+0.5)^{1 / 2}$, subjected to ANOVA (SAS, 2000) and the treatment means compared by the Tukey test at $1 \%$ probability.

\section{RESULTS AND DISCUSSION}

The period of feeding and oviposition of $A$. grandis was similar in all five cultivars, as indicated by the squares used for feeding and oviposition during the flowering and fruiting of plants, from 52 to $136 \mathrm{DAE}$ (Tables 1 and 2). The infestation peaks in the number of squares with $A$. grandis feeding punctures of the five cultivars occurred 77 DAE for cultivar FMX-910 (8.00) and 104 DAE for NuOPAL (8.75), DeltaOPAL (7.50), FMT-701 (4.63) and FMX-993 (8.00) (Table 2). For oviposition, peaks were observed 101 DAE for all cultivars, with little variation in the number of squares with oviposition punctures between cultivars (6.38 for FMX-910 and 5.25 for NuOPAL) (Table 2).

The results showed that the fluctuation in the number of squares used for feeding and oviposition of the pest has the same dynamic, differing only in the number of damaged squares. These results may help to define the best times for sampling, allowing control at the time when the insect population in the area is increasing. 


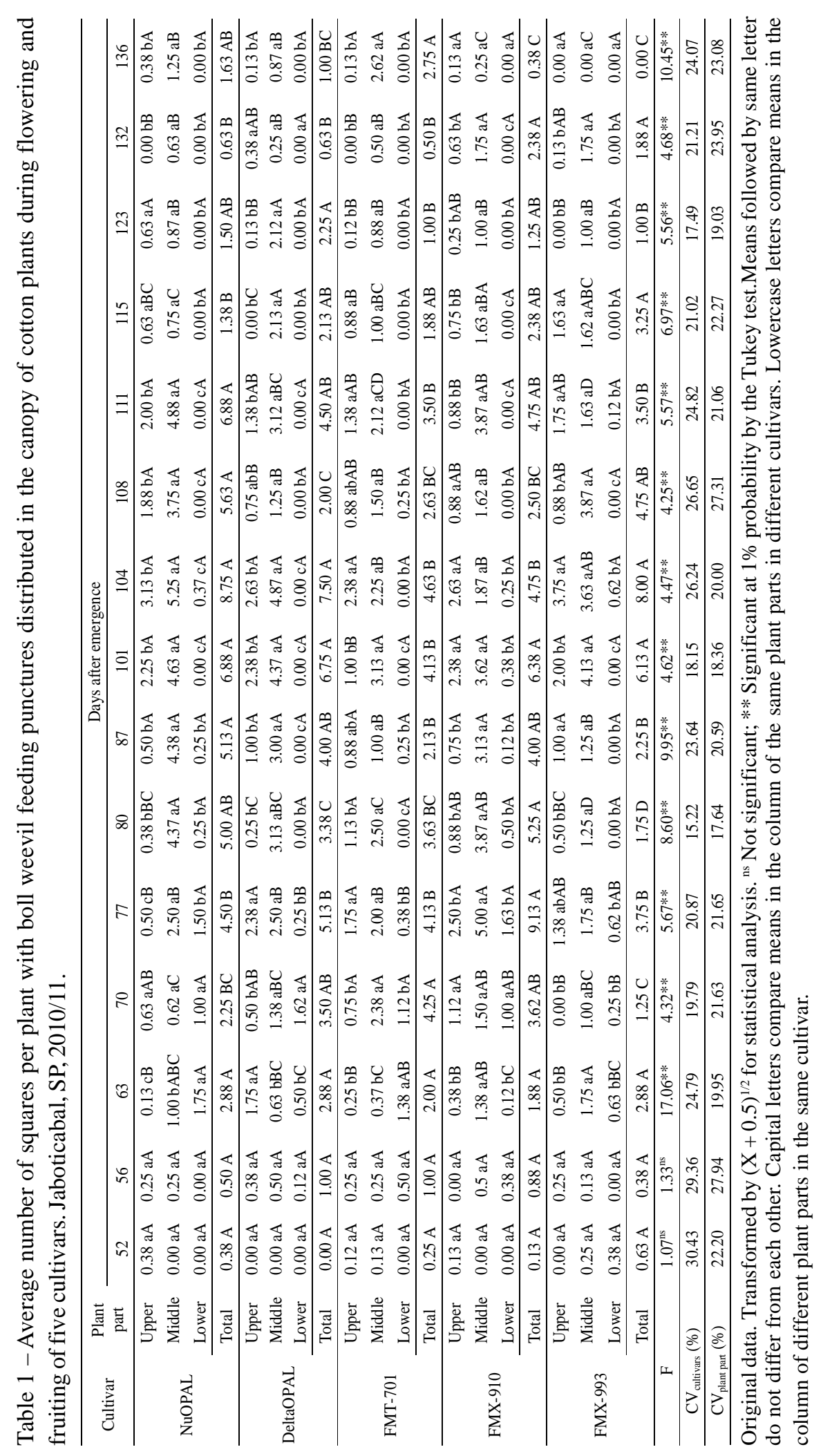




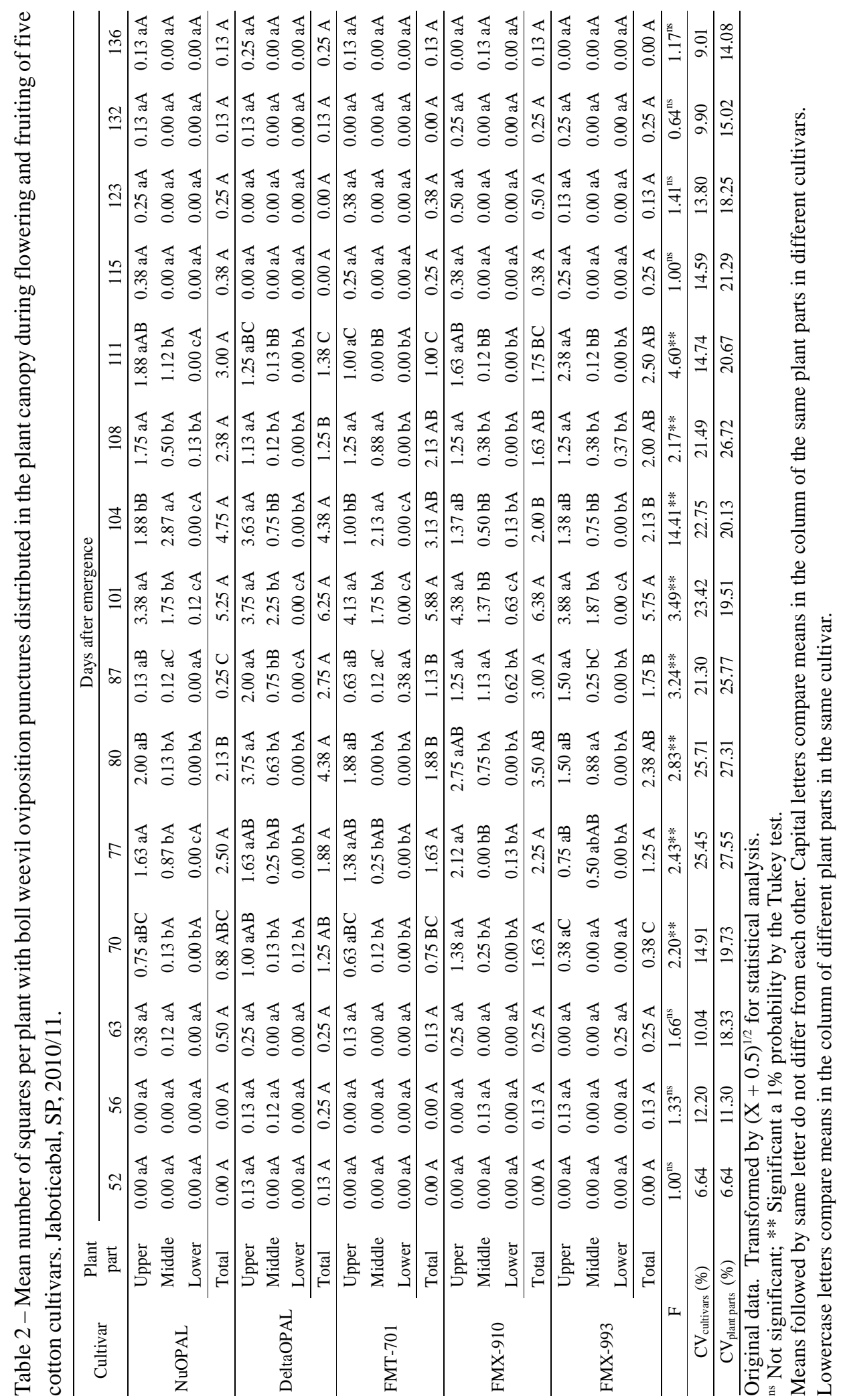


For feeding, the squares of cultivar NuOPAL were preferred by $A$. grandis from 80 to 111 , and 123 to 136 DAE; while DeltaOPAL was preferred 70, from 87 to 104 , and 111 to 123 DAE; FMT-701 was most attacked 70, 115 and 136 DAE; FMX-910 from 70 to 101 and 111 to 132; and cultivar FMX-993 from 101 to 108, 115 and 132 DAE (Table 1). No significant differences among cultivars were observed 52, 56 and $63 \mathrm{DAE}$ due to the low number of squares with feeding punctures of the boll weevil (Table 1). It was seen that the squares of cultivar FMT-701 were used more by the pest at the beginning and end of flowering and fruiting of plants for feeding, while the cultivars NuOPAL, DeltaOPAL, FMX-910, and FMX-993 were used for feeding throughout the period of flowering and fruiting.

The use of cultivars less preferred for feeding by the boll weevil is one of the strategies of integrated pest management for cotton (BUSOLI et al., 2004). The abscission rate of squares from cotton plants infested by the pest is greater when the insect is established in the early development period of these structures (VIEIRA; LIMA, 1999). Accordingly, areas with the cultivar FMT701 , preferred for feeding by the boll weevil in the early flowering and fruiting period of plants, may be more seriously affected than areas with the cultivars NuOPAL, DeltaOPAL, FMX-910, and FMX-993.

The vertical distribution of squares with feeding punctures on the plants indicated significant differences between the three plant parts between 63 and $136 \mathrm{DAE}$ (Table 1).

After 63 days, the pest preferred to feed on the squares of the lower part of plant canopy of the cultivars NuOPAL and FMT-701, the upper part of DeltaOPAL and the middle part of FMX-910 and FMX-993 (Table 1). No differences between the plant parts of the squares with feeding punctures were observed 70 DAE in the cultivars NuOPAL and FMX-910, while the greatest number of squares used for feeding of the pest was recorded in the middle and lower parts of plant canopy of cultivar DeltaOPAL and in the middle part of FMT-701 and FMX993 (Table 1).

From 77 to $136 \mathrm{DAE}$, the feeding behavior pattern of the cotton boll weevil was similar in all cultivars, with preference for squares of the middle and upper part of plant canopy in all evaluations of this period (Table 1).

Cultivar NuOPAL had the greatest number of squares with $A$. grandis feeding punctures in the middle part of plant canopy from 77 to 111 and from 132 to 136 DAE, and in the upper and middle parts from 115 to 123 DAE (Table 1). For cultivar DeltaOPAL, the middle part of plant canopy was preferred from 80 to 104 , from 111 to 123 and 136 DAE; while 77 and 108DAE the feeding preference of the pest was for the middle and upper parts, whereas 132 DAE the preference between parts of plant canopy did not differ significantly (Table 1).

Cultivars FMT-701, FMX-910 and FMX-993 showed differences between the parts of plant canopy. The middle part of cultivar FMT-701 was preferred for feeding by $A$. grandis 80,101 and 123 to $136 \mathrm{DAE}$, while the upper and middle parts were preferred 77,87 and from 104 to $115 \mathrm{DAE}$ (Table 1). The middle part of cultivar FMX-910 was preferred from 77 to 87 and 111 to $132 \mathrm{DAE}$, and the upper and middle parts from 101 to 108 DAE, while 136 DAE there were no differences among the plant parts (Table 1). The most preferred part of cultivar FMX-993 was the middle part 80,101, 108, 123 and $132 \mathrm{DAE}$, and the upper and middle parts 77, 87, 104, 111 and $115 \mathrm{DAE}$, while $136 \mathrm{DAE}$ there were no differences between the parts of plant canopy (Table 1).

It was observed that in every period of cotton flowering and fruiting, squares located in the middle part were predominantly used for $A$. grandis feeding. In some evaluations, this preference was extended to the squares of the upper part of plant canopy. Moreover, in a few evaluations, some cultivars showed no differences between the plant parts.

The results of vertical distribution of squares with A. grandis feeding punctures in this study were obtained with regard to the controlled plant height of five cultivars, managed to grow to a maximum height of $1.2-1.3 \mathrm{~m}$ above the ground. In a similar test performed with no plant height management and without plant growth regulators, Ramalho \& Jesus (1988) found that squares from the upper part of plant canopy were most preferred for A. grandis feeding.

The use of growth regulators and boll ripeners can contribute to the control of the boll weevil, by a uniform production of the cotton-plants, early removal of leaves and small fruits (unripe fruits) from the tips of the cotton plants, eliminating the sources of food and oviposition of A. grandis (SOARES; BUSOLI, 1996). In this study, these variations in feeding behavior of $A$. grandis, preferring squares from the middle part of plant canopy, may have occurred because of the use of growth regulators, causing physiological and morphological changes in cotton plants and, consequently, affecting the insect behavior.

The strongest feeding preference of the cotton boll weevil for the middle part of plant canopy can seriously affect yields, since the insect directly attacks the squares and more than $80 \%$ of the cotton yield is distributed in the 
lower and middle part of plant canopy (SOARES et al., 1999).

Observing the fluctuation of the number of squares with A. grandis oviposition punctures, the squares of cultivar NuOPAL were preferred from 70 to 77 and 101 to 111 DAE; those of DeltaOPAL from 70 to 104 DAE; squares of FMT-701 were preferred 77 and 101 to 108 DAE; those of FMX -910 from 70 to 101 and 108 DAE; and squares of cultivar FMX-993 were preferred from 77 to 80, 104, and 111 to 115 DAE (Table 2). From 52 to 63 and from 115 to 136 DAE no significant differences were observed among cultivars due to the low number of squares with boll weevil oviposition punctures.

It was seen that the squares of cultivar NuOPAL, FMT-701 and FMX-993 were preferred by the pest at the beginning and end of flowering and fruiting of plants for oviposition, while the cultivars DeltaOPAL and FMX-910 were used for oviposition throughout the period of flowering and fruiting.

The results of the vertical distribution of squares with oviposition punctures on the plants indicate that there were significant differences between the infestation of the three parts of plants in the period from 70 to $111 \mathrm{DAE}$ (Table 2). In this period, the oviposition behavior of the boll weevil was similar in all cultivars, preferring to oviposit on squares of the upper part of plant canopy, and some samples indicated a preference for squares in the upper and middle parts (Table 2).

On cultivar NuOPAL, the squares of the upper part of plant canopy were most preferred for boll weevil oviposition in six evaluations (from 70 to 80, 101 and from 108 to $111 \mathrm{DAE}$ ), while the squares of the middle part were preferred $104 \mathrm{DAE}$, and $87 \mathrm{DAE}$ there were no differences between the parts of plant canopy in terms of number of squares with $A$. grandis oviposition punctures (Table 2). Cultivar DeltaOPAL had the greatest number of squares with oviposition punctures in the upper part of plant canopy from 70 to 111 DAE (Table 2).

In cultivar FMT-701, the number of buds with oviposition punctures was highest in the upper part of plant canopy in five assessments $(70,77,80,101$, and $111 \mathrm{DAE})$, in the middle part $104 \mathrm{DAE}$, in the upper and middle parts $108 \mathrm{DAE}$, and no significant differences were observed 87 DAE (Table 2). Of FMX-910, A. grandis preferred the upper part of plant canopy for oviposition from 70 to 80 and 101 to 111 DAE, while 87 DAE there were no differences between the upper and middle parts (Table 2).

In cultivar FMX-993 the number of squares with oviposition punctures did not differ between the parts of plant canopy 70 DAE, whereas 77 and 80 DAE the upper and middle parts were preferred by the insect. In the evaluations from 87 to $111 \mathrm{DAE}$, the insect preferred to lay eggs in squares of the upper part of plant canopy of this cultivar (Table 2).

According to the results obtained, it is possible to observe that in every period of plant flowering and fruiting, squares located in the upper part were predominantly used for oviposition of $A$. grandis. In some evaluations, this preference was also extended to the squares located in the middle part of plant canopy. Moreover, in a few evaluations, no differences of preference between the parts of plant were recorded in some cultivars.

These results of the vertical distribution of $A$. grandis oviposition punctures were similar to those obtained by Ramalho and Jesus (1988), who found that the boll weevil preferred the squares located in the upper part of plant canopy to lay its eggs.

In the evaluations of this study in the different phenological stages of the cotton cultivars it was found that the boll weevil feeds preferentially on buds of the upper and middle parts of plant canopy, and that it lays its eggs preferentially in squares of the upper part of plant canopy. This suggests that sampling the middle and upper parts of cotton plants may be important for research purposes and for the productive sector, making the process of damage assessment more efficient and making a determination of the pest infestation levels possible for an adequate chemical control of $A$. grandis, within a safe and reliable range. Moreover, this information must be considered in the development of new pest sampling plans, to reduce the sampling time and increase the reliability of results.

\section{CONCLUSIONS}

Anthonomus grandis prefers to lay eggs in squares of the upper part of cotton plant canopy;

The insect prefers to feed on squares of the upper and middle part of plant;

The cultivar FMT-701 is preferred by the boll weevil for feeding at the beginning of the flowering and fruiting period, and cultivars NuOPAL, DeltaOPAL, FMX-910 and FMX-993 are used throughout the period of cotton flowering and fruiting;

The cultivars NuOPAL, FMT-701 and FMX-993 are preferred for $A$. grandis oviposition at the beginning and end of flowering and fruiting of plants, while the cultivars DeltaOPAL and FMX-910 are used for oviposition throughout the period of flowering and fruiting; and All cultivars were used for oviposition of the boll weevil in every period of cotton flowering and fruiting. 


\section{ACKNOWLEDGEMENTS}

To the Coordenação de Aperfeiçoamento de Pessoal de Nível Superior (CAPES) for financial support.

\section{REFERENCES}

BUSOLI, A.C. et al. Preferência alimentar do bicudo-doalgodoeiro por frutos de diferentes cultivares e idades. Pesquisa Agropecuária Brasileira, Brasília, v.39, n.2, p.101-104, 2004.

BUSOLI, A.C.; SOARES, J.J.; LARA, F.M. O bicudo do algodoeiro e seu manejo. Jaboticabal: Funep, 1994. 32p.

ELLSWORTH, P.C.; MARTÍNEZ-CARRILLO, J.L. IPM for Bemisia tabaci: a case study from North America. Crop Protection, Guildford, v.20, p.853-869, 2001.

FERNANDES, M.G. et al. Distribuição vertical de lagartas de Alabama argillacea (Hüebner) (Lepidoptera: Noctuidae) em plantas de algodoeiro.

Manejo Integrado de Plagas y Agroecología, Turrialba, v.78, p.28-35, 2006.

NARANJO, S.E.; FLINT, H.M. Spatial distribution of adult Bemisia tabaci (Homoptera: Aleyrodidae) in cotton and development and validation of fixedprecision sampling plants for estimating population density. Environmental Entomology, Lanham, v.24, p.261270, 1995.

RAMALHO, F.S.; JESUS, F.M.M. Distribution of boll weevil (Anthonomus grandis Boheman) eggs within cotton plants. Tropical Agriculture, Trinidad, v.65, n.3, p.245-248, 1988.

RIBEIRO, P.A. et al. Alternative food sources and overwintering feeding behavior of the boll weevil, Anthonomus grandis Boheman (Coleoptera: Curculionidae) under the tropical conditions of central Brazil. Neotropical Entomology, Londrina, v.39, n.1, p.2834, 2010.
SAS Institute Inc. SAS/C OnlineDoc ${ }^{\mathrm{TM}}$, Ver.8. SAS Institute, Inc., Cary, NC, 2000.

SHOWLER, A.T. Influence of adult boll weevil (Coleoptera: Curculionidae) food resources on fecundity and oviposition. Journal of Economic Entomology, Lanham, v.97, p.1330-1334, 2004.

SHOWLER, A.T. Relationships of different cotton square sizes to boll weevils (Coleoptera: Curculionidae) in field conditions. Journal of Economic Entomology, Lanham, v.98, p.1574-1579, 2005.

SOARES, J.J.; BUSOLI, A.C. Efeito dos reguladores de crescimento vegetal nas características agronômicas do algodoeiro e no controle de insetos. Pesquisa

Agropecuária Brasileira, Brasília, v.31, n.1, p.37-41, 1996.

SOARES, J.J. et al. Influência da posição do fruto na planta sobre a produção do algodoeiro. Pesquisa Agropecuária Brasileira, Brasília, v.35, n.5, p.755-759, 1999.

SOUSA, D.M.G.; LOBATO, E. Calagem e adubação para culturas anuais e semiperenes. In: SOUSA, D.M.G; LOBATO, E. (Ed.). Cerrado: correção do solo e adubação. 2. ed. Brasília: Embrapa, 2004.p. 283-315.

TRICHILO, P.J.; WILSON, L.T.; MACK, T.P. Spatial and temporal dynamics of the threecornered alfalfa hopper (Homoptera: Membracidae) on soybeans. Environmental Entomology, Lanham, v.22, p.802-809, 1993.

VIEIRA, R.M.; LIMA, E.F. Resistência às pragas do algodoeiro. In: BELTRÃO, N.E.M. (Ed.). O agronegócio do algodão no Brasil. Brasília: Embrapa, 1999. p.317-360.

WILSON, L.T.; GUTIERREZ, A.P.; HOGG, D.B. Withinplant distribution of cabbage looper, Trichoplusia $n i$ (Hübner) on cotton: development of a sampling plan for eggs. Environmental Entomology, Lanham, v.11, p.251254, 1982. 